\title{
Mechanisms to manage intellectual property in collaborative innovation projects ${ }^{1}$
}

\author{
María del Socorro López Gómez \\ University of Antioquia \\ socolopezg@gmail.com \\ James Alberto Morales Chincha \\ University of Antioquia \\ jammorales11@gmail.com \\ José Edinson Aedo-Cobo \\ University of Antioquia \\ j.eacobo@gmail.com
}

\begin{abstract}
This paper presents some mechanisms for managing Intellectual Property (IP) in collaborative innovation projects, especially those using co-creation techniques. The mechanisms selection was made from a documentary review that allowed to identify the essential elements that could be condensed into a cycle including phases, such as negotiation, protection, assessment, commercialization, among others. According to the literature, these mechanisms must be supported in an institutional policy that guides strategies and organizational processes, mostly those focusing on the product development from the co-creation techniques. The mechanisms presented were formed considering the innovation process used in the ARTICA ${ }^{2}$ alliance and those
\end{abstract}

1 This paper was written in the context of the macro-project of co-creation of the Alianza Regional in TIC Aplicada - ARTICA, financed by the University of Antioquia, the EAFIT University, the Pontifical Bolivarian University and UNE-EPM Telecomunicaciones, to whom we extend our gratitude for making it easier for us to obtain access to resources and information, as well as knowledge of the executives and experts that took part in the fieldwork. We especially thank Professor José Edinson Aedo Cobo for his unconditional support of the design of this proposal and the intellectual property team from the Corporación Tecnnova, led by Maira Catalina Betancur Monsalve and Alejandra Echeverri Jaramillo, who from their expertise supported the validation of the proposal.

2 ARTICA is a center of excellence located in the city of Medellín, Colombia, and it is composed of the University of Antioquia, the National University, The EAFIT University, the Pontifical Bolivarian University, the IPS Universitaria and UNE EPM Telecomunicaciones. 
that have been worked in the literature. Also, they were submitted to experts who work with intellectual property in innovation processes for their validation.

Keywords: intellectual property, intellectual property management, intellectual property management model, co-creation, collaborative innovation.

\section{Introduction}

This work is the result of a project in which an Intellectual Property Management model (IPM) was constructed in order to be used in collaborative development processes, especially those using innovation techniques based on co-creation. For the development of the model, four main sources were used: the review of the literature regarding IPM, mechanisms and instruments of protection in innovation processes; the observation and analysis of methodological processes used in the identification of new products with co-creation techniques; the innovation model of Alianza Regional en TIC Aplicadas ${ }^{3}$ (ARTICA), based on the interactive model from Kline and Rosenberg; and, finally, the opinion of experts in IP who work in the protection and commercialization of the developed products. This paper develops one of the components of the IPM model, referring to the instruments and tools that allow systematizing the management process. The fundamental contribution consists of the integrated and systemic presentation of these mechanisms that were scattered in the literature or that have been used empirically in different processes, not necessarily collaborative innovation; however, in the analysis, it was found that their application is relevant in the co-creation techniques.

\section{The co-creation techniques within the concept of open innovation}

Since Henry Chesbrough (2003) coined the term open innovation, a wave of literature about the concept and the way of making open innovation emerged, giving rise to a broad discussion in this regard. However, Chesbrough (2015) has explained that the conceptual interpretation of open innovation has been distorted, and in many cases it has been reduced to the supply chain taking part in the innovation process. Innovation focuses on external processes, and the importance of Inside Out has been ignored. Open innovation goes far beyond this narrow concept. New products and services are created by a wide range of agents, such as universities, public and private research organizations, venture

3 A center of excellence in Colombia 
capital, competitors and customers or users of the services, among others. The purpose is to incorporate that external knowledge into internal knowledge that the organization has gained during the innovation process.

...we define open innovation as a distributed innovation process based on purposively managed knowledge flows across organizational boundaries, using pecuniary and non-pecuniary mechanisms in line with the organization's business model. These flows of knowledge may involve knowledge inflows to the focal organization (leveraging external knowledge sources through internal processes), knowledge outflows from a focal organization (leveraging internal knowledge through external commercialization processes) or both (coupling external knowledge sources and commercialization activities)... (Chesbrough and Bogers, 2014, p 17).

Therefore, it must be understood that if the innovation concept is very complex, the open innovation concept will involve a higher complexity both to address it and to manage it, and to obtain valuable results of its process.

It is here, in this concept of open innovation, that the co-creation techniques take their meaning. For example, Piller (2010) states that the co-creation term was introduced to define strategies of open innovation that actively involve the participation of customers in the design and construction of goods and services, in which ideas are produced, valued by organizations and the customers themselves. In this sense, for Vargo and Lusch (2008 a and b), the co-creation is the participation with customers in order to get value.

The co-creation process can be initiated with the group of possible ideas, clusters, to continue with the structuring by making them more robust, which permits the design of services or prototypes. And finally, it finishes with the development and market test (Ribes and Peralt, 2014).

Ruiz-Moreno et alii (2014) developed the co-creation concept from the theory of resources and abilities in which, one of the keys to create and keep the competitive advantage over competitors lies in getting resources and abilities that are unique, valuable, irreplaceable and difficult to imitate (Barney, 1991). According to these authors, it is not the possession and control of those resources that make an organization competitive, but rather its ability to articulate and transform them so that they can be perceived with a higher value by the customer. From here, it arises the current need to create innovations together with the customers and the proactivity of the organizations to generate changes from the opportunities found.

Co-creation is a useful methodology that can be used in the processes of ideation by refining ideas, or in the design and the final prototyping of the product 
or service. If we take innovation models, we can use the methodology in the exploration, design and assessment phase. However, it is necessary that different kinds of people with a different experience level, in regards to a particular subject (knowing or being related to the problem), take part, as well as a group of experts who immediately guide, lead, characterize and analyze the obtained data.

The co-creation techniques seek collaborative development of new products, hand-in-hand with the end customer, accelerating the process of market introduction of new products or services, given that the end users involved in the process have validated key features of these innovations. Additionally, use value is added to the co-creative process, as it is produced according to needs identified by the customers themselves (Ramaswamy, 2009; Paasi et alii, 2010a; Rodríguez et alii, 2011; Ruiz-Moreno et alii, 2014; Xiaoyi and Chaoming, 2014). For its implementation, it is necessary that the participant agents share tacit knowledge relevant to the process, that they interact with it and have the ability of generate new knowledge (Leiponen, 2008; Paasi et alii, 2010b). Also it is required that the organization lead the methodological process of such implementation (Morales, 2014).

\section{Intellectual Property (IP) and the importance in the valuation of innovation results}

The economy based on knowledge is supported in the innovation processes. However, the innovation process ceased to be conceived as one of ingenuity of some privileged brains and companies with business acumen to become a transversal social process in all areas and economic sectors, mediated today, as all human activities, by the market. This social process is generated in the interaction of social agents that produce, use, and commercialize knowledge (López, 2008). This presents high complexity in the negotiation of the results of products derived from the creative processes involving the participation of multiple actors.

Many innovations fail because their contribution to intellectual capital is not established; if the innovation is protected or not by a copyright, a patent, trademark or any other intellectual property right (IPR), what value is it and what right is being transferred to the new creation? Vulnerability exists in the co-creation processes due to claims regarding violations of intellectual property, for instance, for using previous protected knowledge, which is not revealed or is ignored by the contributors. Likewise, in these processes, actors that took part in very early stages can claim property over results, but the transfer for the subsequent developments is not established. Additionally, in the development 
process of the new product, it may happen that it is not defined clearly when, how, where and by means of what mechanisms the results of the creative process can and must be protected.

Moreover, in the vast majority of cases, the value conferred by a patent, a utility model, the registration of an industrial design, accompanied by brands, or even proper management of a business secret is much higher than the value of the product that has no protection and, in many cases, the unprotection can lead the open innovation project to failure. Therefore, proper management of IPR in any process of innovation is inherent to the process itself.

The IPM in collaborative innovation projects contributes to the consolidation of agreements of a different nature among participants to carry out joint innovation projects; it makes the protection and thus the commercialization of the obtained results easier (Al-Aali and Teece, 2013; Fisher III and OberholzerGee, 2013).

\section{Mechanisms of the IP management}

Any management process requires the design of policies to guide and define the limits and powers in the decision making that produce value. Therefore, under the model of innovation, designing IP policies creates the context for the definition and use of the mechanisms. According to Blomqvist et alii (2005); Kaiser (2010); Salazar and Silva (2010); Payumo et alii (2012); Allarakhia (2013); Londoño (2014); Mejia (2014); Xiaoyi and Chaoming (2014) and Bstieler et alii (2015), the policies should include both the organization's innovative model, and the resources and capabilities which it has, so that it allows management to, among other things:

- Facilitate the ownership management to establish relationship guidelines between organizations or others involved in an innovation project, whether or not possessing IPR.

- Facilitate the design of processes, tools and clauses to make it easier to use and protect information and strategic knowledge deemed to be confidential.

- Facilitate the design process that helps to determine if the result can be the object of legal protection, and the best strategy to carry it out.

+ Propose methods of assessment and preparation of the results.

- Provide bases that serve as a starting point to negotiate the results (ownership, percentages of royalties, etc.). 
- Establish the minimum requirements and conditions to do technology transfer processes and knowhow.

- Propose methods for the development of technology and management of knowhow.

These are some of the considerations that must be taken into account in the design of policies, which address how to lift and establish processes and tools to facilitate IP protection and, at the same time, support the construction of IPM models as an approximation to the realities faced by some organizations (Hertzfeld et alii, 2006; Lopez et alii, 2009; Orozco, 2010; Salazar and Silva, 2010; Cao and Zhao, 2011; Payumo et alii, 2012). Chart 1 proposes meeting points between the actions contained in the innovation model by the ARTICA alliance, the methodology phases of co-creation, and the IPM.

\section{Chart 1. Relationship between the innovation model of the Arctica alliance, the co-creation and the susceptible stages to IPM.}

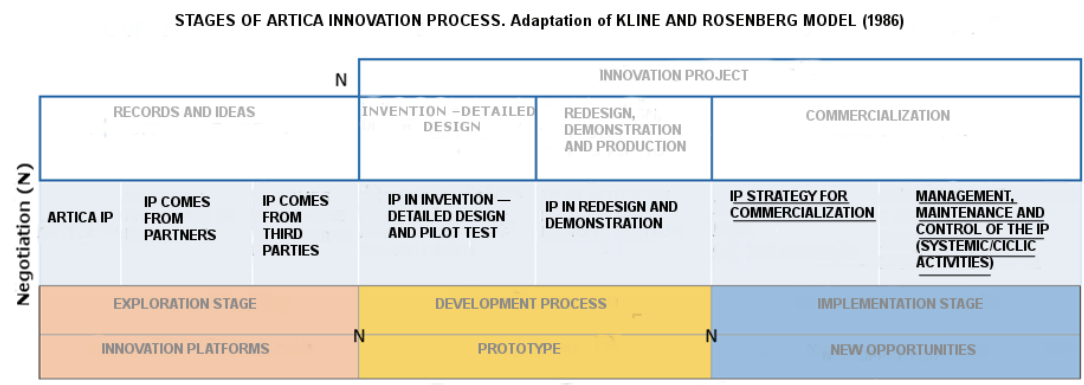

STAGES OF COLLABORATIVE INNOVATION PROCESS USING CO-CREATION TECHNIQUES

Source: Self made structure from David, M.L.; semi-structured interview ${ }^{4}$ with members of the ARTICA alliance (February 14, 2014; April 8, 2014; April 15, 2014; May 23, 2014).

According to the innovation model of the ARTICA alliance, which was built on Kline and Rosenberg's innovation model, IPM mechanisms are presented for each of the stages that are involved: exploration, development and implementation stage. Chart 2 shows said model with the IP milestones to manage at each stage.

4 The semi-structured interview seeks to understand specific aspects of a particular topic through a formal conversation. In this type of interview, open questions are used so that people's knowledge and experience showcase their perception of the object of study (Ardèvol et alii, 2003) 
Chart 2. IPM proposed model for collaborative innovation projects using co-creation techniques.

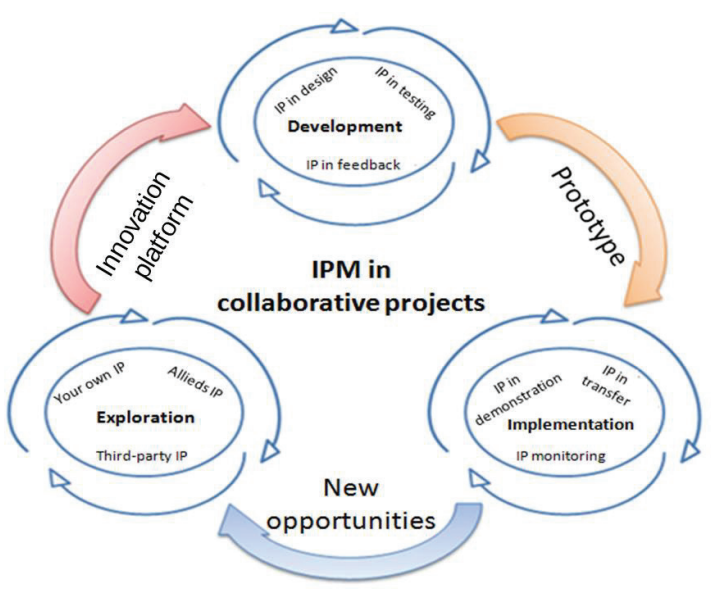

Source: from Lopez (2008) and ARCTICA's IP Manual (internal document of the alliance).

Chart 1 shows that it is mandatory in the exploration stage to have policies and mechanisms to identify and manage your own IP. In the development stage, the IP arising is managed in the design, testing and feedback processes. Finally, in the implementation stage, the IP is considered in relation to the demonstration and the transfer; and the IP produced is tracked in the new product or service created. This makes it possible to present the mechanisms to manage the IP in the context of collaborative innovation projects that use co-creation techniques for the development of goods and services in the following table: 
Table 1: Mechanisms of Intellectual Property

\begin{tabular}{|c|c|c|c|}
\hline Stage & Mechanism & Description of the mechanism & $\begin{array}{l}\text { Target of intellectual } \\
\text { property rights }\end{array}$ \\
\hline \multirow{3}{*}{ 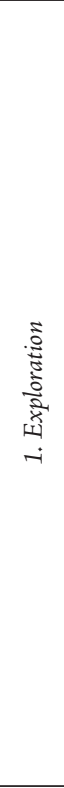 } & $\begin{array}{l}\text { Intellectual } \\
\text { property agreement }\end{array}$ & $\begin{array}{l}\text { - Contributions from each participant (form } \\
\text { and value) } \\
\text { - Statement of prior knowledge, technologies } \\
\text { and knowhow to its value and property rights } \\
\text { it confers. } \\
\text { - Indemnity clauses } \\
\text { - Confidentiality clauses }\end{array}$ & \multirow{3}{*}{$\begin{array}{l}\text { Technology and } \\
\text { knowhow that belonging } \\
\text { to: } \\
\text { The own organization, } \\
\text { your allies and other } \\
\text { organizations }\end{array}$} \\
\hline & Proceedings & $\begin{array}{l}\text { - Participants } \\
\text { - Entry or exit of participants } \\
\text { - Key considerations } \\
\text { - Decisions } \\
\text { - Intellectual property implications }\end{array}$ & \\
\hline & Tracking records & $\begin{array}{l}\text { - Any product that can be protected by intellec- } \\
\text { tual property rights } \\
\text { - Contributions in prior knowledge, knowhow, } \\
\text { methodologies, financial resources, human, } \\
\text { etc. } \\
\text { - Generation of new knowledge and creations } \\
\text { - Participation of natural persons or companies } \\
\text { at each stage of the project } \\
\text { - Any measure to ensure the protection of in- } \\
\text { tellectual property of intangible assets arising } \\
\text { in the project }\end{array}$ & \\
\hline \multirow{4}{*}{ 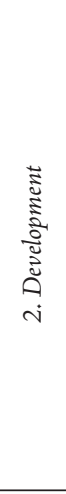 } & $\begin{array}{l}\text { Agreements and / } \\
\text { or confidentiality } \\
\text { statements }\end{array}$ & $\begin{array}{l}\text { Generally, all aspects of product development, } \\
\text { their potential uses, impacts, scope and users } \\
\text { could be protected by way of confidentiality } \\
\text { agreements }\end{array}$ & \multirow{4}{*}{ Design testing feedback } \\
\hline & $\begin{array}{l}\text { Cession of property } \\
\text { rights }\end{array}$ & $\begin{array}{l}\text { By developers and participants of the entity that } \\
\text { will commercialize the technology or that will } \\
\text { make the transfer process or that continue the } \\
\text { development }\end{array}$ & \\
\hline & $\begin{array}{l}\text { Authorization for } \\
\text { use of data }\end{array}$ & $\begin{array}{l}\text { Personal data that can be used as inputs in the } \\
\text { creative process }\end{array}$ & \\
\hline & $\begin{array}{l}\text { Authorization for } \\
\text { use of photographic } \\
\text { records, video and } \\
\text { audio }\end{array}$ & They can be used as inputs in the creative process & \\
\hline 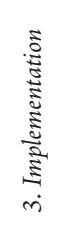 & $\begin{array}{l}\text { Business models } \\
\text { supported by } \\
\text { IP. structuring } \\
\text { technology packages }\end{array}$ & $\begin{array}{l}\text { - Patents } \\
\text { - Utility models } \\
\text { - Industrial designs, } \\
\text { - Knowhow protected by trade secret, } \\
\text { - Distinctive signs (brands, quality certificates, } \\
\text { among others } \\
\text { - Copyright }\end{array}$ & $\begin{array}{l}\text { Commercialization } \\
\text { transfer } \\
\text { follow-up to the IP } \\
\text { licensed or operated by } \\
\text { self-employed }\end{array}$ \\
\hline \multicolumn{4}{|c|}{ Policies And Strategies } \\
\hline
\end{tabular}

\section{Source: Authors' elaboration}




\section{Stage 1: Exploration}

It seeks to identify opportunities to add value to goods and/or existing services or consider the design of new ones. To achieve this, it is necessary to use specific co-creation techniques, technological monitoring studies, resource analysis and organizational capabilities, feasibility studies (if any), market analysis, among others, to identify both the IPR holders and users, customers and partners that will use the knowledge (Al-Aali and Teece, 2013; Loiola and Mascarenhas, 2011; Orozco, 2010). At this stage, the IP agreements are made to regulate the form and the value of the participants' contributions, as well as the IP rights conferred to them; in a document the statements of technology and knowhow are included, along with the indemnity clauses, minutes of each meeting, logs and other records to be carried out under the project, bearing in mind three centers where you can manage IP.

- The own IP including all IPR as well as the knowhow belonging to the organization. Hence, it is recommended to identify and make inventories about existing technologies, emphasizing the elements of the technology knowledge chain (Paasi et alii 2010a; Salazar and Silva, 2010; Van Triest and Vis 2007).

- The IP of allies including all IPR as well as the knowhow belonging to the organizations partnered with the collaborative innovation project. In this component, it is important to consider the agreements reached, the way in which technology is planned to be incorporated, and if there are licenses or usage restrictions about it (Al-Aali and Teece, 2013).

- In third party IP, that is to say IPR from organizations that are not part of the collaborative innovation project, it is decisive to have licenses for the use and incorporation of protected technologies in the project ( $\mathrm{Al}$ Aali and Teece, 2013).

\section{Stage 2: Development}

At this stage, leaders should monitor the signing of non-disclosure agreements and confidentiality statements, transfer of property rights, data using authorizations, authorization to use photographic records, video and audio, etc., since it is possible to have concepts, prototypes and evaluated escalations to propose business models for the goods and services being developed (Kaiser, 2010). The IPM at this stage focuses on the design, testing and feedback processes of the co-creation project. 
- The IPM in design: It is related to the proper use of prior knowledge and to the respect for third party IPR (Conley et alii, 2013.).

- The IPM in testing: It is important to keep model agreements or to sign non-disclosure agreements with specialized institutions or experts that will support the testing in order to safeguard the relevant information which, if disclosed, could affect the future protection of the developments. It is also necessary for the characteristics of the co-creation that the customers or end-users authorize the use of photographic records, video and audio, as well as personal data since these are inputs to the creative process (Rivette and Kline, 2000).

+ The IPM in the feedback: In this phase, it is expected that experts, customers, the research and development team or any agent of the alliance provide feedback of the results so decisions can be made about the course of the project and the developments obtained, as well as the technologies that have been incorporated in it. (Xiaoyi and Chaoming, 2014). At this stage, it is possible to make decisions that involve:

- starting the protection process under any IP mechanism;

- abandoning, in the process, incorporated technologies, which, if they have some protection, require a renegotiation of licenses;

- incorporating other IPR protected technologies, which will involve the negotiation of licensing or its acquisition;

- developing new technologies to make viable the implementation or functionality of the developments achieved so far.

\section{Stage 3: Implementation}

At this stage, the configuration of business models supported by IPR involves structuring technology packages in which different IP mechanisms (patents, utility models, industrial designs, integrated circuits, knowledge protected by trade secrets, trademarks or copyright) may add significant value (Kaiser, 2010; Orozco, 2010; Fisher III and Oberholzer-Gee, 2013). It is important to utilize formal agreements to ensure confidentiality and other important factors in this process. The IPM, at this stage, focuses on marketing processes, monitoring and transferring of the licensed IP or exploited IP.

Marketing and transfer: It must be determined the type of license to be transferred, methods to be used, support, updates, possible future developments that licensed and licensor can make in regards to technology (Blomqvist et alii, 2005; Xiaoyi and Chaoming, 2014). 
IPM in monitoring: It can be supported in scientometrics and patentometrics, as well as with scans that allow new projects to advance supported in existing databases and allow one to visualize the possibility of creating new business models with current developments or see the need to develop new products (Castellanos et alii, 2011). Besides, these studies also provide information about the use being made of technology and if third parties are taking advantage unduly.

Finally, policies and processes should be intertwined with macro and micro strategies so that they can articulate the internal capabilities and resources (specific from the organization) and external (specific from the allies and third parties) to develop high-value added products that can be protected and marketed (Wiig, 1997; Rivette and Kline, 2000; Chesbrough, 2006; Orozco, 2010; Schmal et alii, 2010; Alexy and Reitzig, 2012; Al-Aali and Teece, 2013; Conley et alii, 2013; Fisher III and Oberholzer-Gee, 2013).

\section{Conclusions}

In the literature review, we found widely documented open innovation processes. However, the techniques of co-creation are still exposed in a very generic way. Mainly, the conceptual aspects are developed, while the techniques themselves are little documented or arguably not referenced at all. It seems that these techniques remain in the field of knowhow as a competitive factor for consultants. Moreover, the literature on the importance of IP and protection mechanisms is quite large, however, the same cannot be said regarding references found on the management of IP, and even less was found on open innovation processes and the use of co-creation techniques. Management of IP in innovation processes is highly complex, given the uncertainty inherent in the innovation itself; it is even more complex in open innovation processes, in which multiple actors are involved in different phases of the creative development process, dissemination and marketing a result. Actors can be in and out at any stage of the process, making it difficult to establish the proportion of participation, quality and, therefore, the value of it. It was not found in the literature reviewed a systemic, holistic, integrated and comprehensive approach that contributes to the management of intellectual property rights in open innovation processes with the use of cocreation techniques.

Proper management of IP in open innovation projects that use co-creation techniques is essential for two reasons. First, an adequate protection of the results generates also some other added values. This protection makes marketing of the project easier while supporting the consolidation of relationships among the actors in the process, giving also more transparency at negotiations. Secondly, 
proper management reduces the potential risk of claims by third parties or disagreements among the participants.

The proposed mechanisms to manage IP included in this document should be analyzed in the context of the resources and capabilities that each organization has, so that, strategically, we develop or adapt intellectual property managing practices more in line with the needs of the entity. In this regard, the management of IP in collaborative innovation projects is facilitated when there are policies, processes or clear framework agreements that guide the actions of partner organizations in these projects and facilitates them to act facing expected and unexpected results, avoiding conflicts or unnecessary and costly discussions.

It was evident that the co-creation is a complex process of collaborative innovation in the ARTICA Alliance because it constantly requires the incorporation of technologies and knowledge that, in many cases, are protected by one or more forms of IP. This means that the mechanisms proposed are feasible to use in organizations that are similar to those of a Centre of Excellence and Innovation. In other organizations, the process may be more complex, considering that the IPM strategy must change and adapt to the required context. Nevertheless, this proposal can facilitate the management of IP, protection of the obtained results, as well as valuation, negotiation, sale and transfer, since it collects scattered practices in the literature and is fed back by specialists managing innovation projects and IP. It should also be taken into account that collaborative innovation processes, and specifically those involving co-creation techniques, have a great amount of information from the environment, interaction with a large number of agents involved in one or more stages of development, and also incorporate technologies and protected knowledge by one or more forms of IP.

Acknowledgments

This research was supported by: CODI-University of Antioquia (2015-2016 Sustainability Strategy, University of Antioquia) and the project of co-creation of the Alianza Regional en Tic Aplicada; Manager group - Faculty of Economics; and SISTEMIC Group - Faculty of Engineering of the University of Antioquia. We give special thanks to the team of IP at the Tecnnova Corporation for their support in reviewing the IPM proposal. 


\section{Bibliographic References}

Al-Aali, A. Y., and Teece, D.J. (2013)." Towards the (Strategic) Management of Intellectual Property: Retrospective and prospective". California Management Review, 55(4), 15-30. doi:10.1525/cmr.2013.55.4.15

Alexy, O., and Reitzig, M. (2012). "Managing the business risks of open innovation". Mckinsey Quarterly, (1), 17-21.

Allarakhia, M. (2013). "Open-source approaches for the repurposing of existing or failed candidate drugs: Learning from and applying the lessons across diseases". Drug Design, Development and Therapy, 7, 753-766.

Ardèvol, E.; Bertrán, M.; Callén, B., and Pérez, C. (2003). "Etnografía virtualizada: la observación participante y la entrevista semiestructurada en línea". Athenea digital, 3, 72-92.

BARnEY, J. (1991). "Firm resources and sustained competitive advantage". Journal of Managenent, 17(1): 99-120.

Blomqvist, K.; Hurmelinna, P., and Seppänen, R. (2005). "Playing the collaboration game right-balancing trust and contracting". Technovation, 25(5), 497-504.

Bstieler, L.; Hemmert, M., and Barczak, G. (2015). "Trust formation in university-industry collaborations in the U.S. biotechnology industry: IP policies, shared governance, and champions". Journal of Product Innovation Management, 32(1), 111-121.

CAO, Y., and ZHAO, L. (2011). "Intellectual property management model in enterprises: a technology life cycle perspective". International Journal of Innovation E Technology Management, 8(2), 253-272.

Castellanos Domínguez, O. F.; Fúquene Montañez, A. M., and Ramírez Martínez, D. C. (2011). Análisis de tendencias de la información bacia la innovación. Bogota: National University of Colombia.

Chesbrough, H. W. (2003). Open Innovation: The New Imperative for Creating and Profiting from Technology. Harvard Business School Press. Boston, Massachusetts.

Chesbrough, H. W. (2006). Open Business Models: How to Thrive in the New Innovation Landscape. Harvard Business School Press Books, 1.

Chesbrough, H. and Bogers, M. (2014). "New Frontiers in Open Innovation, chapter 1". Oxford University Press, 2014. Recovered from: <https://books. google.com.co/books?isbn $=0191504998>$ [Access December 2015].

Chesbrough, H. W. (2015). Open Innovation: More Than Supply Chain Management. Garwood Center for Corporate Innovation. Recovered from 
$<$ http://garwoodblog.corporateinnovation.berkeley.edu/open-innovationas-more-than-supply-chain-management/ $>$ [Access December 2015].

Conley, J. G.; Bican, P. M., and Ernst, H. (2013). "Value Articulation: A framework for the strategic management of intellectual property". California Management Review, 55(4), 102-120. doi:10.1525/cmr.2013.55.4.102.

David, M. L. (s.f.). "Fortalecimiento de la innovación con co-creación” [PDF]. EAFIT University; recovered from: <http://www.eafit.edu.co/cice/ emprendedores-eafit/Documents/fortaleciendo-la-innovacion-con-la-cocreacion.pdf $>$ [Access August 1, 2014].

Fisher III, W. W., and Oberholzer-Gee, F. (2013). "Strategic Management of Intellectual Property: an Integrated Approach". California Management Review, 55(4), 157-183, doi:10.1525/cmr.2013.55.4.157.

Hertzfeld, H. R.; Link, A. N., and Vonortas, N. S. (2006). “Intellectual property protection mechanisms in research partnerships". Research Policy, $35(6), 825-838$.

KaIser, L. (2010). "Management of intellectual property in research and development: a search for systems from the viewpoint of research and technology organizations". International Journal of Innovation E Technology Management, 7(3), 263-272. doi:10.1142/S0219877010002033.

Leiponen, A. (2008). "Control of intellectual assets in client relationships: implications for innovation”. Strategic Management Journal, 29(13), 13711394.

Loiola, E., and Mascarenhas, T. (2013). "Gestão de Ativos de Propriedade Intelectual: um Estudo sobre as Práticas da Braskem S.A. (Portuguese)". RAC - Revista De Administração Contemporânea, 17(1), 42-63.

Londoño, M (2014). "Políticas para la gestión estratégica de propiedad intelectual”. En Atehortúa, C.; Cetina, D.; Yepes, E.; Gonzáles, H.; Rendón, J.; Mejía, J.; Granados, J; Jaramillo, L.; Londoño, M.; Betancur, M.; Velásquez, M.; Quintero, O., and Peralta, S. Guía estratégica de propiedad intelectual universidad empresa-Corporación TECNNOVA UEE. (pp. 48-58). Medellin: Vallejo Editores.

López, M. (2008). Hacia una gestión universitaria de los derechos de propiedad industrial: patentes: Las patentes universitarias en Colombia, Chile y España. Cap 8. Spain: University of the Basque Country.

López, S.; Simón, R. S.; Gómez, F. C., and Toвón, C. G. (2009)."The processes involved in a management model for university patents". [Los procesos en un modelo de gestión de patentesuniversitarias] Ingenieria e Investigacion, 29(2), $135-141$. 
Mejía, J. (2014). "Valoración de la propiedad intelectual”. En Atehortúa, C.; Cetina, D.; Yepes, E.; Gonzáles, H.; Rendón, J.; Mejía, J.; Granados, J*; Jaramillo, L.; Londoño, M.; Betancur, M.; Velásquez, M.; Quintero, O, and Peralta, S. Guía estratégica de propiedad intelectual universidad empresa-Corporación TECNNOVA UEE. (pp. 202-213). Medellin: Vallejo Editores.

Morales, H. H. (2014). Co-creación ¿Diálogo activo entre organizaciones $y$ comunidades de interés? (Master's thesis University of Antioquia). Recovered from <http:// http://ayura.udea.edu.co:8080/jspui/ bitstream/123456789/589/1/JH0906.pdf> [Acceso 10 Octubre de 2014].

Orozco, D. (2010). "Legal knowledge as an intellectual property management resource davidorozco legal knowledge as an intellectual property management resource". American Business Law Journal, 47(4), 687-726. doiæ10.1111/ j.1744-1714.2010.01107.x.

PaAsi, J*; Luoma, T.; Valkokari, K., and Lee, N. (2010a). "Knowledge and intellectual property management in customer-supplier relationships". International Journal of Innovation Management, 14(4), 629-654. doiः10.1142/ S1363919610002805.

Paasi, J.; Valkokari, K.; Rantala, T.; Hytönen, H.; Nystén-Haarala, S., and Huhtilainen, L. (2010b). "Innovation management challenges of a system integrator in innovation networks". International Journal of Innovation Management, 14(6), 1047-1064.

Payumo, J.; Gang, Z.; Pulumbarit, E.; Jones, K.; Maredia, K., and Grimes, H. (2012). "Managing intellectual property and technology commercialization: Comparison and analysis of practices, success stories and lessons learned from public research universities in developing Asia". Innovation: Management, Policy E Practice, 14(4), 478-494.

Piller, F.T.; Ihl, C. and Vossen, A. (2010). "A typology of customer co-creation in the innovation process", Social Science Research Network, 4, pp. 1-26.

Ramaswamy, V. (2009). "Está preparado para la co-creación?" IESE Insight (Spanish Edition), (2), 29-35.

Ribes-Giner, G., and Peralt-Rillo, A. (2014). "Métodos y técnicas facilitadoras de la co-creation innovation en programas máster para el mercado del postgrado." Intangible Capital, 10(1), 101-124. doi:10.3926/ ic. 443 .

Rivette, K. G., and Kline, D. (2000). Discovering new value in intellectual property. Harvard Business Review, 78(1), 54-66. 
Rodríguez, N.; Álvarez, B., and Vijane, M. (2011). "Aplicación de la Lógica Dominante del servicio (LDS) en el sector turístico: el marketing interno como antecedente de la cultura de co-creación de innovaciones con clientes y empleados". Cuadernos De Gestión, 11(2), 53-75. doi\$10.5295/cdg.100238ng.

Ruiz-Moreno, A.; Ortega-Egea, T.; Haro-Domínguez, C., and RoldánBravo, M. (2014). "El proceso de co-creación de valor y su impacto en la estrategia de innovación en empresas de servicios". Intangible Capital, 10(2), 266-293, doi:10.3926/ic.504.

Salazar, S., and Silva, J. (2010). Guía para la gestión de la propiedad intelectual en consorcios regionales de investigación agrícola. IICA, FONTAGRO - San José, C.R.+ IICA.

Schmal, R.; López, S.; Cabrales, F., and Acuña, D. (2010). "Modeling of business processes for the management of patents in universities". [Modelado de Procesos de Negocio para la Gestión de Patentes en Universidades] Informacion Tecnologica, 21(6), 113-124.

VAN Triest, S., and Vis, W. (2007). "Valuing patents on cost-reducing technology: A case study". International Journal of Production Economics, 105(1), 282-292. doi:10.1016/j.ijpe.2006.04.019

VArgo, S. L. and Lusch, R. F. (2008a)."Why «service»?" Journal of the Academy of Marketing Science, 36, 25-38.

VArgo, S. L. and Lusch, R. F. (2008b). "Service-dominant logic: continuing the evolution". Journal of the Academy Marketing Science, 36, 1-10.

WIIG, K. M.(1997). "Integrating intellectual capital and knowledge management.” Long Range Planning, 30(3), 399-405+323-324.

Xiaoyi, D., and Chaoming, L. (2014). "An AHP-GA-BP Algorithm for Evaluation of Enterprise Collaborative Innovation Management of Intellectual Property Rights". International Journal of U - E E-Service, Science E Technology, 7(1), 91-101. doi\$10.14257/ijunesst.2014.7.1.09. 